\title{
The Effects of Oxidized Low Density Lipoproteins on Inducible Mouse Macrophage Gene Expression Are Gene and Stimulus Dependent
}

\author{
Thomas A. Hamilton, * Jennifer A. Major, ${ }^{\star}$ and Guy M. Chisolm \\ Departments of *Immunology and ${ }^{\ddagger}$ Cell Biology, Research Institute, Cleveland Clinic Foundation, Cleveland, Ohio 44195
}

\begin{abstract}
Oxidized LDL has been previously reported to suppress the expression of genes induced in mononuclear phagocytes by inflammatory stimuli. In this study we extend these findings to demonstrate that the suppressive effects of oxidized LDL vary depending upon the gene being monitored and the stimulus being used to induce or enhance its expression. The expression of a selection of LPS-inducible genes exhibited differential sensitivity to pretreatment with oxidized LDL. Furthermore, the ability of oxidized LDL to suppress gene expression varied markedly with the inducing stimulus used. TNF $\alpha$ and IP-10 mRNA expression induced by IFN $\gamma$ and IL-2 was markedly more sensitive to suppression by oxidized LDL than that induced by LPS. The cooperative effects of IFN $\gamma$ and LPS on the expression of the inducible nitric oxide synthase gene were suppressed by oxidized LDL while the antagonistic effect of IFN $\gamma$ on LPS-induced expression of the TNF receptor type II mRNA was not altered. The suppressive activity of LDL was acquired only after extensive oxidation and was localized in the extractable lipid component. These results suggest a potent and direct connection between the oxidative modification of LDL and the chronic inflammation seen in atherogenic lesions. Furthermore, the appreciable selectivity of oxidized LDL in mediating secondary control of cytokine gene expression demonstrates that the active material(s) is targeted to disrupt specific intracellular signaling pathways. (J. Clin. Invest. 1995. 95:2020-2027.) Key words: modified low density lipoproteins - mononuclear phagocytes - leukocytes - cytokines • atherosclerosis
\end{abstract}

\section{Introduction}

The role of mononuclear phagocytes in atherosclerosis is supported by multiple lines of experimental observation (1-4). Monocytes from the circulation adhere to appropriately activated endothelial cells, traverse the endothelium and basement membrane, and subsequently enter the intimal space of the artery wall. Under atherogenic conditions, these cells accumulate lipoprotein lipid and acquire the characteristic morphology of foam cells which compose the fatty streak, a primary histologic

Address correspondence to Dr. Thomas Hamilton, The Department of Immunology (NN1-06), The Cleveland Clinic Foundation, 9500 Euclid Avenue, Cleveland, OH 44195. Phone: 216-444-6246; FAX: 216-4449329.

Received for publication 5 August 1994 and in revised form 14 December 1994.

J. Clin. Invest.

(c) The American Society for Clinical Investigation, Inc.

0021-9738/95/05/2020/08 \$2.00

Volume 95, May 1995, 2020-2027 feature of incipient atherosclerosis. The accumulation of lipid within macrophages appears to be mediated by their selective recognition and uptake of oxidatively modified LDL (5).

In addition to being selectively internalized by macrophages, oxidized LDL can alter the function of monocytes and macrophages in ways that appear to promote atherogenesis (617). Oxidized LDL and its lysophosphatidylcholine moiety are chemotactic for monocytes but reduce the motility of tissue macrophages $(6,7)$. Oxidized LDL also stimulates the expression of adhesion proteins which mediate the capture of monocytes on the endothelial surface (8-11). Oxidatively modified LDL can promote or suppress the expression of inflammatory cytokines in endothelial cells and mononuclear phagocytes, respectively (12-16). For example, oxidized LDL suppresses the expression of $\mathrm{TNF} \alpha$ and $\mathrm{IL}-1 \alpha$ in murine peritoneal macrophages and IL-1 $\alpha, \mathrm{IL}-1 \beta, \mathrm{IL}-6$, and PDGF in human monocytes in culture (14-16). These effects have been convincingly linked to oxidized forms of LDL whereas native $\mathrm{LDL}$, acetylated LDL, and malondialdehyde-modified LDL are all inactive (14-17). Examination of cytokine expression in atherogenic lesion sites in vivo using either immunohistochemistry or in situ hybridization demonstrates macrophage expression of proinflammatory cytokines (18-24). Interestingly, in one study, the magnitude of expression is diminished or missing in regions proximal to the lesion core where cells may accumulate higher levels of oxidized lipid or have been exposed to LDL which has been more extensively oxidized (19). These findings could be interpreted to connect directly the presence of lipid-loaded macrophages in the fatty streak with the action of oxidized lipoprotein in promoting maturation of such lesions into mature atheromas. Cytokine expression in either endothelial cells or newly recruited macrophages may be initiated or potentiated by moderately oxidized LDL, thus promoting the development of a localized inflammatory reaction. Macrophages which have been present in the vessel wall for extended time periods may have such inflammatory responses suppressed by internalization of extensively oxidized LDL. This could result in the development of an unresolving, chronic state of inflammation leading to the recruitment and proliferation of smooth muscle cells and the excessive deposition of extracellular matrix by their progeny.

To understand how oxidized lipids more precisely may impact on the inflammatory process and the potentially complex interplay between different cell types and different cytokine products, we have examined how oxidized LDL affects the expression of a set of inducible macrophage genes. Because these genes can be induced by multiple agents, the stimulus selectivity of oxidized LDL was also examined. The results clearly demonstrate differential sensitivity to oxidized LDL among the panel of inducible genes examined. The expression of many of these genes can be altered by IFN $\gamma$ either alone or in combination with other agents, including LPS and IL-2 (25, 26). The expression of IP-10 and TNF $\alpha$ was markedly more sensitive to suppression by oxidized LDL when stimulated by IFN $\gamma$ and IL- 2 than by LPS. The effects of IFN $\gamma$ in combination 
with LPS were also differentially affected in cells pretreated with oxidized LDL. These findings indicate that oxidized LDL suppresses only selected portions of the intracellular signaling pathways used in macrophages for regulation of inflammatory gene expression induced by extracellular stimuli.

\section{Methods}

Reagents. Brewer's thioglycollate broth (TG) ${ }^{1}$ was purchased from Difco Laboratories Inc. (Detroit, MI). NZY broth, RPMI 1640 medium, and Dulbecco's modified Eagle's medium were obtained from GIBCO BRL (Grand Island, NY). Hanks' balanced salt solution and phosphatebuffered saline (PBS) were from Mediatech, Inc. (Herndon, VA). Fetal bovine serum and the Limulus amoebocyte lysate assay kit were obtained from BioWhittaker, Inc. (Walkersville, MD). Deoxyribonucleoside triphosphates were purchased from Pharmacia AB (Uppsala, Sweden). Restriction enzymes, random priming kits, and recombinant murine IFN $\gamma$ were purchased from Boehringer Mannheim (Indianapolis, IN). IL-2 was generously provided by Cetus-Chiron Inc. (Emeryville, CA). Du Pont/New England Nuclear (Boston, MA) was the source of [ $\alpha$ $\left.{ }^{32} \mathrm{P}\right] \mathrm{dCTP}$. Tris, sodium dodecyl sulfate (SDS), acrylamide, $N, N^{\prime}$-methylene-bisacrylamide, urea, and protein assay reagent were obtained from Bio-Rad (Hercules, CA). LPS prepared by Westphal phenolic extraction from Escherichia coli (0111:B4) was obtained from Sigma Immunochemicals (St. Louis, MO). All reagents contained $<100 \mathrm{pg} / \mathrm{ml}$ of endotoxin as determined by Limulus amoebocyte lysate assay.

Mice. Specific pathogen-free, inbred C57B1/6 mice 9-12 wk of age were purchased from the Trudeau Institute (Saranac Lake, NY). Precautions were taken such that the animals remained free from infection by environmental pathogens to ensure that the degree of spontaneous activation of tissue macrophages would be minimal (27).

Cell culture. TG-elicited macrophages were obtained as reportedly previously $(25,26)$. Peritoneal lavage was performed using $10 \mathrm{ml}$ of cold HBSS containing $10 \mathrm{U} / \mathrm{ml}$ heparin. Macrophages in RPMI 1640 containing glutamine, penicillin, streptomycin, and 5\% FBS (culture medium) were plated in 100- or 150-mm plastic Petri dishes, incubated for $2 \mathrm{~h}$ at $37^{\circ} \mathrm{C}$ in an atmosphere of $5 \% \mathrm{CO}_{2}$, washed three times with HBSS to remove nonadherent cells, and equilibrated in culture medium for $18 \mathrm{~h}$ before initiation of each experiment.

Preparation of plasmid DNA. The plasmids encoding the genes for TNF $\alpha$, IL-1 $\beta$, TNF receptor type II (TNFRII), IP-10, inducible nitric oxide synthase (iNOS), D3, and D8 were described previously $(25,28-$ 33). The plasmid encoding glyceraldehyde 3-phosphate dehydrogenase (GAPDH) was obtained from Dr. David Stern (Columbia University, New York). Methods for plasmid DNA preparations were as described by Sambrook et al. (34). $1 \mu \mathrm{g}$ of plasmid DNA was radiolabeled by nick translation with $\left[\alpha-{ }^{32} \mathrm{P}\right] \mathrm{dCTP}$. The resultant specific activity was $\sim 10^{8} \mathrm{cpm} / \mu \mathrm{g}$, which was used at $10^{7} \mathrm{cpm}$ per blot.

Preparation of RNA and Northern analysis. Each assay used $1 \times 10^{7}$ macrophages cultured in $60-\mathrm{mm}$ diameter plastic Petri dishes for preparation of total RNA. After treatment of the cells for the indicated times with the indicated stimuli, total cellular RNA was extracted by the guanidine isothiocyanate-cesium chloride method (35). Samples of total RNA $(5 \mu \mathrm{g})$ were separated on a $1 \%$ agarose/2.2 $\mathrm{M}$ formaldehyde gel and subsequently blotted onto MAGNA nylon membrane with $20 \times$ SSC by capillary transfer according to previously published methods (34). The RNA was crosslinked to the membrane with an ultraviolet crosslinker (Stratagene, La Jolla, CA). The blots were prehybridized for 8$12 \mathrm{~h}$ at $42^{\circ} \mathrm{C}$ in $50 \%$ formamide, $1 \%$ SDS, $5 \times$ SSC, $1 \times$ Denhardt's solution $(0.02 \%$ Ficoll, $0.02 \%$ BSA, $0.02 \%$ polyvinylpyrrolidone), 0.25 $\mathrm{mg} / \mathrm{ml}$ denatured salmon sperm DNA, and $50 \mathrm{mM}$ sodium phosphate (pH 6.5) and then hybridized with $1 \times 10^{6} \mathrm{cpm} / \mathrm{ml}$ of $\left[\alpha-{ }^{32} \mathrm{P}\right] \mathrm{dCTP}$ radiolabeled cDNA plasmid probe at $42^{\circ} \mathrm{C}$ for $16-24 \mathrm{~h}$. After hybridiza-

1. Abbreviations used in this paper: GAPDH, glyceraldehyde 3-phosphate dehydrogenase; iNOS, inducible nitric oxide synthase; TG, thioglycollate broth; TNFRII, TNF receptor type II. tion, blots were washed with $0.1 \%$ SDS, $2 \times$ SSC for $30 \mathrm{~min}$ at room temperature followed by two washes at $55^{\circ} \mathrm{C}$. The blots were then exposed using XAR-5 $x$-ray film with intensifying screens at $-70^{\circ} \mathrm{C}$. Expression of GAPDH was used as an internal control for the quantity of total mRNA on each lane of the gel and this control was applied in all experiments.

Transcriptional analysis. Cultures of $4 \times 10^{7}$ macrophages in 150$\mathrm{mm}$ culture dishes were treated as indicated in the text and nuclei isolated as described previously (26). Transcription initiated in intact cells was allowed to complete in the presence of $\left[\alpha-{ }^{32} \mathrm{P}\right] \mathrm{UTP}$ and the RNA was isolated and hybridized to slot-blotted plasmids containing specific cDNA inserts ( $7 \mu \mathrm{g}$ DNA/slot) essentially as described elsewhere (26). Blots were exposed to $\mathrm{x}$-ray film for $72-96 \mathrm{~h}$ at $-70^{\circ} \mathrm{C}$ as described above.

Preparation and oxidation of $L D L$. Human LDL was isolated as described previously (14). Oxidized LDL was prepared by dialyzing native LDL against PBS, $\mathrm{pH} 7.2$, for $24 \mathrm{~h}$ to remove EDTA, and subsequently against PBS containing $10 \mu \mathrm{M} \mathrm{CuSO}_{4}$ for $72 \mathrm{~h}$. Oxidation was terminated by dialysis against PBS containing $0.5 \mathrm{mM}$ EDTA for at least $24 \mathrm{~h}$. Conditions of LDL preparation and oxidation were designed to minimize the contamination of samples with endotoxin (14). Extracts of oxidized LDL were prepared using chloroform/methanol as described in Bligh and Dyer (36). The organic phase was dried under nitrogen and stored at $-70^{\circ} \mathrm{C}$. Before use the dried lipid extracts were reconstituted in a 1:1 mixture of ethanol/dimethylsulfoxide and added to culture medium to a final concentration of $0.25 \%$ ( vol/ $\mathrm{vol})$. Control cultures received comparable amounts of solvent. The level of LDL oxidation was monitored as the accumulation of thiobarbituric acid reactive substances (TBARS) as described elsewhere (14). Concentrations of oxidized LDL were based upon LDL cholesterol content before oxidation measured as reported previously (14).

Measurement of TNF $\alpha$ protein. The secretion of TNF $\alpha$ was measured using the Factor-Test-X Mouse TNF $\alpha$ ELISA kit from Genzyme Corp. (Cambridge, MA) according to the manufacturer's instructions. TG-elicted macrophages were plated in 24-well culture plates and allowed to adhere for $2 \mathrm{~h}$ before vigorous washing to remove nonadherent cells. Individual cultures were treated as indicated in the text with either native or oxidized LDL at up to $400 \mu \mathrm{g} / \mathrm{ml}$ for $24 \mathrm{~h}$. Cultures were washed three times to remove residual LDL and incubation continued in fresh medium containing LPS, IFN $\gamma$, and IL-2 or no treatment as indicated for $24 \mathrm{~h}$. Cultures were also provided with $1 \mu \mathrm{Ci} / \mathrm{ml}\left[{ }^{3} \mathrm{H}\right]-$ leucine (Dupont/New England Nuclear). Culture medium was harvested, centrifuged to remove nonadherent cells and cell debris, and used for ELISA. The cell layer was solubilized in $100 \mu$ l of $1 \%$ SDS solution, $1 \mathrm{ml}$ of $10 \%$ trichloroacetic acid was added, and the precipitated protein was collected on glass fiber filters before determination of radioactivity by scintillation spectrometry. The levels of TNF $\alpha$ protein in each sample were normalized to the level of $\left[{ }^{3} \mathrm{H}\right]$ leucine incorporation.

\section{Results}

Suppression of macrophage inflammatory gene expression by oxidized $L D L$ is gene and stimulus dependent. Previously reported studies from this laboratory examined the effects of oxidized LDL pretreatment on the expression of TNF $\alpha$ and IL- $1 \alpha$ genes induced in murine macrophages by maleylated BSA (14). To determine if a broader spectrum of LPS-sensitive genes might be influenced by oxidized LDL, elicited peritoneal macrophages from C57Bl/6 mice were pretreated with oxidized LDL $(400 \mu \mathrm{g} / \mathrm{ml})$ for $24 \mathrm{~h}$ and then stimulated with the indicated concentrations of LPS for $4 \mathrm{~h}$. The concentration of oxidized LDL used was the minimum amount required to modulate expression of the least sensitive gene based upon studies presented below in Fig. 3. Total RNA was then analyzed by Northern hybridization using a panel of radiolabeled cDNAs encoding IL- $1 \beta$, TNF $\alpha$, the chemokine IP-10, and two LPS-inducible genes of unknown functional identity (D3 and D8) $(25,33)$. 


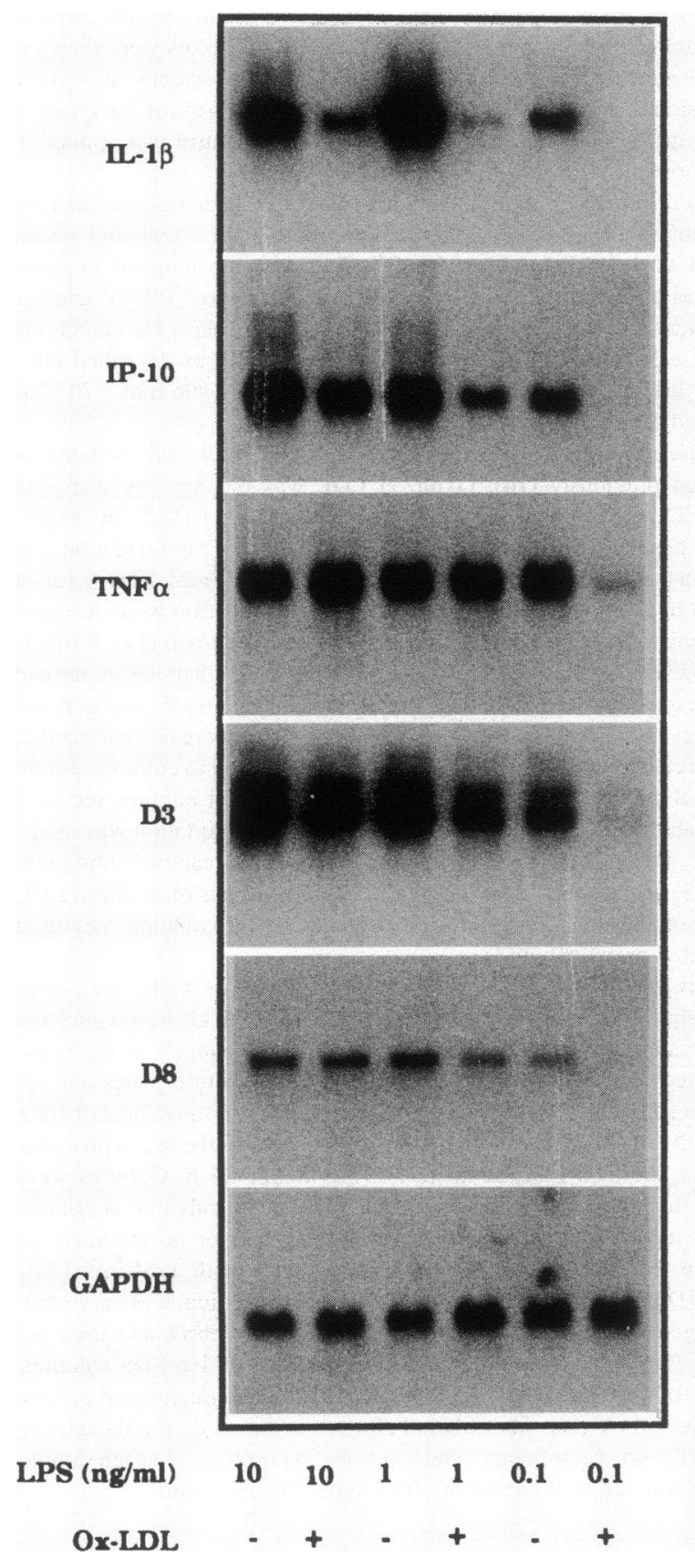

Figure 1. Suppression of LPS-induced gene expression in macrophages by oxidized LDL depends on the gene and concentration of LPS. 2 $\times 10^{7}$ TG-elicited peritoneal macrophages were untreated or treated with oxidized LDL ( $400 \mu \mathrm{g} \mathrm{LDL}$ cholesterol $/ \mathrm{ml}$ ) for $24 \mathrm{~h}$. The culture medium was changed and the cultures were subsequently stimulated with the indicated concentrations of LPS for $4 \mathrm{~h}$ before preparation of total RNA and analysis by Northern hybridization as described in Methods. Blots were hybridized with the indicated radiolabeled cDNAs and films were exposed for $18 \mathrm{~h}$. Similar results were obtained in two separate experiments.

LPS stimulation of otherwise untreated macrophages induced strong expression of all five mRNAs and was optimal at $\geq 1$ $\mathrm{ng} / \mathrm{ml}$ (Fig. 1). Pretreatment of cultures with oxidized LDL selectively affected the levels of individual mRNAs. Expression of IL- $1 \beta$ mRNA was suppressed at all concentrations of LPS. IP-10 expression was suppressed only when the cultures were stimulated with $1 \mathrm{ng} / \mathrm{ml}$ or less of LPS. TNF $\alpha, \mathrm{D} 3$, and D8 mRNAs were heavily suppressed only when doses of $0.1 \mathrm{ng} /$ ml LPS were used. In this circumstance the amount of LPS added was suboptimal and suppression could have been due to association of LPS with residual oxidized LDL bound on the cell surface. Levels of GAPDH mRNA were not altered by any of these treatments.

Many inducible macrophage genes including those examined in the experiment presented in Fig. 1 are also expressed in macrophages treated with IFN $\gamma$ or a combination of IFN $\gamma$ and IL-2 $(25,26,37)$. This provided an opportunity to determine if the sensitivity of macrophage gene expression to pretreatment with oxidized LDL varied with the inducing stimulus. Macrophages exposed to either native or oxidized LDL alone exhibited no difference from untreated controls (Fig. 2). Cultures stimulated simultaneously with IFN $\gamma$ and IL-2 exhibited expression of both IP-10 and TNF $\alpha$ mRNA which was comparable in magnitude to that seen after stimulation with LPS. Pretreatment with oxidized LDL markedly suppressed the expression of both genes when the stimulus was IFN $\gamma / \mathrm{IL}-2$, while TNF $\alpha$ or IP-10 mRNA expression induced by LPS was either unaffected or only modestly suppressed by oxidized LDL, consistent with the results shown in Fig. 1. Unmodified native LDL had no effect on the expression of any gene induced by any stimulus.

Combinations of IFN $\gamma$ and either IL-2 or LPS can also cooperatively promote expression of iNOS, though the response to IFN and LPS is much stronger than to IFN and IL-2 (Fig. 2) $(32,38,39)$. The expression of iNOS mRNA was strongly suppressed in macrophage cultures pretreated with oxidized but not native LDL regardless of the stimulus used. IFN $\gamma$ is also a potent antagonist of LPS-induced expression of TNFRII mRNA (31). Macrophages pretreated with medium alone, native LDL, or oxidized LDL all exhibited the same pattern of inducible TNFRII mRNA expression, indicating that, for this gene, neither the stimulatory effects of LPS nor the inhibitory activity of IFN $\gamma$ were affected by the oxidized LDL exposure (Fig. 2).

In previously published work, the suppression of maleylated albumin-induced TNF $\alpha$ mRNA levels by oxidized LDL was maximal at an LDL concentration of $\sim 100 \mu \mathrm{g} / \mathrm{ml}$ LDL protein (14). To determine if the differential effects of oxidized LDL on inducible macrophage genes varied with the concentration of oxidized LDL, the dose dependence of suppression of individual genes was assessed. Cultures were pretreated with the indicated concentrations of oxidized LDL for $24 \mathrm{~h}$ before stimulation with IFN $\gamma$ and IL-2 and analysis of specific mRNA levels (Fig. 3). Expression of IL-1 $\beta$, IP-10, and TNF $\alpha$ mRNAs was optimally suppressed in cultures treated with between 50 and 100 $\mu \mathrm{g} / \mathrm{ml}$ oxidized LDL. Maximal suppression of iNOS mRNA levels, however, required oxidized LDL levels of $400 \mu \mathrm{g} / \mathrm{ml}$. While oxidized LDL treatment has been reported to produce cytotoxicity in various cell types, the exposure of peritoneal macrophages to $400 \mu \mathrm{g} / \mathrm{ml}$ for $24 \mathrm{~h}$ had no effect on protein synthesis as measured by the incorporation of $\left[{ }^{3} \mathrm{H}\right]$ leucine into trichloroacetic acid precipitable material (data not shown). This lack of toxicity in murine macrophages is consistent with our previous experience (14). Because this treatment was not associated with toxicity and was the minimum concentration sufficient to produce the maximal effect on the least sensitive gene (i.e., iNOS), it was used in other experiments.

To determine if the suppression of IFN $\gamma / \mathrm{IL}-2-$ induced gene expression by oxidized LDL was mediated by inhibition of transcription, nuclear run-on studies were performed. Peritoneal macrophage cultures were pretreated or not with oxidized LDL 


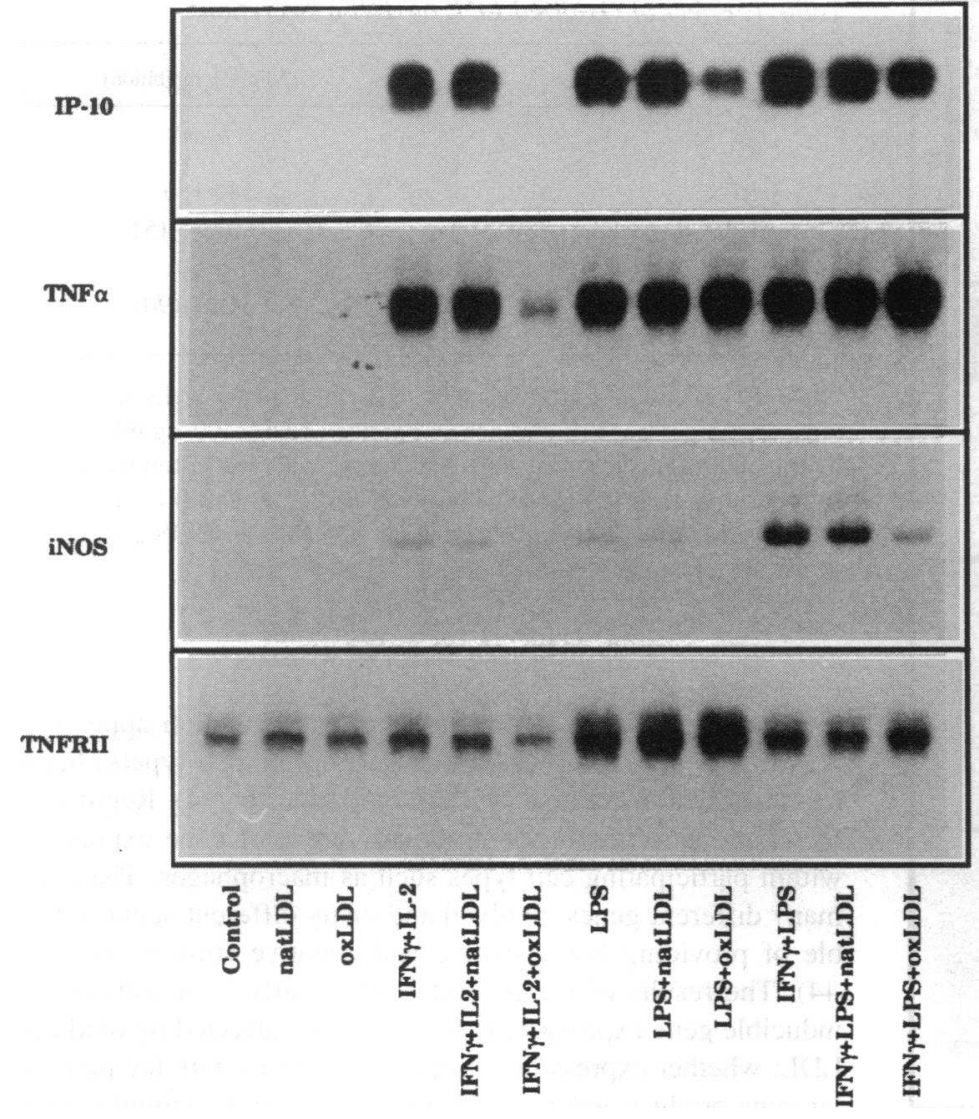

Figure 2. Suppression of inducible macrophage gene expression by oxidized LDL varies with the stimulus. TG-elicited macrophages were cultured in medium alone or medium containing native LDL or oxidized LDL (both at $400 \mu \mathrm{g} / \mathrm{ml}$ ) for $24 \mathrm{~h}$ and then stimulated with IFN $\gamma(100 \mathrm{U} / \mathrm{ml})$ plus IL-2 (500 $\mathrm{U} / \mathrm{ml})$, LPS ( $10 \mathrm{ng} / \mathrm{ml})$, or IFN $\gamma$ plus LPS for $4 \mathrm{~h}$ before analysis of gene expression as described in the legend to Fig. 1. Blots were hybridized with the indicated CDNA probes and films were exposed for 12-48 h. Similar results were obtained in three separate experiments. for $24 \mathrm{~h}$ and then stimulated with either LPS or IFN $\gamma$ and IL-2 for $2 \mathrm{~h}$. Nuclei were prepared and transcription initiated before harvest was allowed to continue in vitro in the presence of radiolabeled UTP. The isolated RNA transcripts were subsequently hybridized with cDNAs blotted onto nylon membranes. Both IFN $\gamma / \mathrm{IL}-2$ and LPS were able to stimulate the frequency of transcription of the TNF $\alpha$ gene (Fig. 4). In agreement with the results of Northern hybridization studies reported in Fig. 2, the IFN $\gamma / \mathrm{IL}-2$-induced transcription was strongly suppressed by pretreatment of cultures with oxidized LDL while there was little or no effect on the transcription frequency for the TNF $\alpha$ gene in LPS-stimulated macrophages. Similar results were seen when the IP-10 gene was analyzed (data not shown). Transcription from the GAPDH gene was unaltered by any of the treatment conditions.

TNF $\alpha$ expression is known to be regulated by both transcriptional and translational mechanisms (40). To verify that the suppressive effects of oxidized LDL resulted in a lower production of the gene product itself, the levels of TNF $\alpha$ protein in culture medium from either LPS- or IFN $\gamma / \mathrm{IL}-2-$ stimulated macrophages were measured using a commercial ELISA. Both LPS and IFN $\gamma / \mathrm{IL}-2$ treatments resulted in the release of immunochemically detectable TNF $\alpha$ protein from peritoneal macrophages (Table I). At stimulus doses yielding similar levels of TNF $\alpha$ secretion, oxidized LDL suppressed the production of TNF $\alpha$ by $90 \%$ in IFN $\gamma / \mathrm{IL}-2-$ treated cells but only by $50 \%$ in LPS-treated cells.

Suppression of gene expression requires extensively oxidized $L D L$. To determine how the suppressive activity of modified lipoprotein might vary with the extent of oxidation, macrophages were pretreated with preparations of LDL which had been oxidized by dialysis against $10 \mu \mathrm{M} \mathrm{Cu}^{2+}$ for varying time periods. Interestingly, the ability to suppress IP-10 mRNA expression induced by IFN $\gamma$ and IL-2 was not acquired until LDL had been oxidized for at least $24 \mathrm{~h}$ and was optimal by $48-72$ $h$ (Fig. 5). While there was some variability between different preparations of oxidized LDL, the differences were generally quantitative (data not shown). The results presented in this report have been obtained with oxidized LDL obtained from three different preparations.

The oxidation of LDL produces alterations in both the protein moiety (apo B100) and the lipid components of the particle (41). To determine what oxidation products are involved in the suppression of gene expression, macrophages were pretreated with chloroform/methanol extracts of the oxidized LDL before stimulation with IFN $\gamma$ and IL-2. Extracts were dried under nitrogen and solubilized in a 1:1 mixture of ethanol and DMSO. Dilution of the lipid mixture into culture medium was performed to allow a concentration of solvent of no greater than $0.25 \%$ and this had no detectable effect on stimulus-induced gene expression. The extract at levels equivalent to $1 \mathrm{mg}$ of preextraction LDL protein per ml of culture medium effectively suppressed the IFN $\gamma / \mathrm{IL}-2$-induced elevation of IP-10 mRNA (Fig. 6).

\section{Discussion}

Mononuclear phagocytes play an important role in the pathophysiology of atherosclerosis. This cell type may provide a connection between two key etiologic features of the disease: the oxidation of lipoproteins present in the vessel wall and the development of a chronic inflammatory reaction at the site. The 


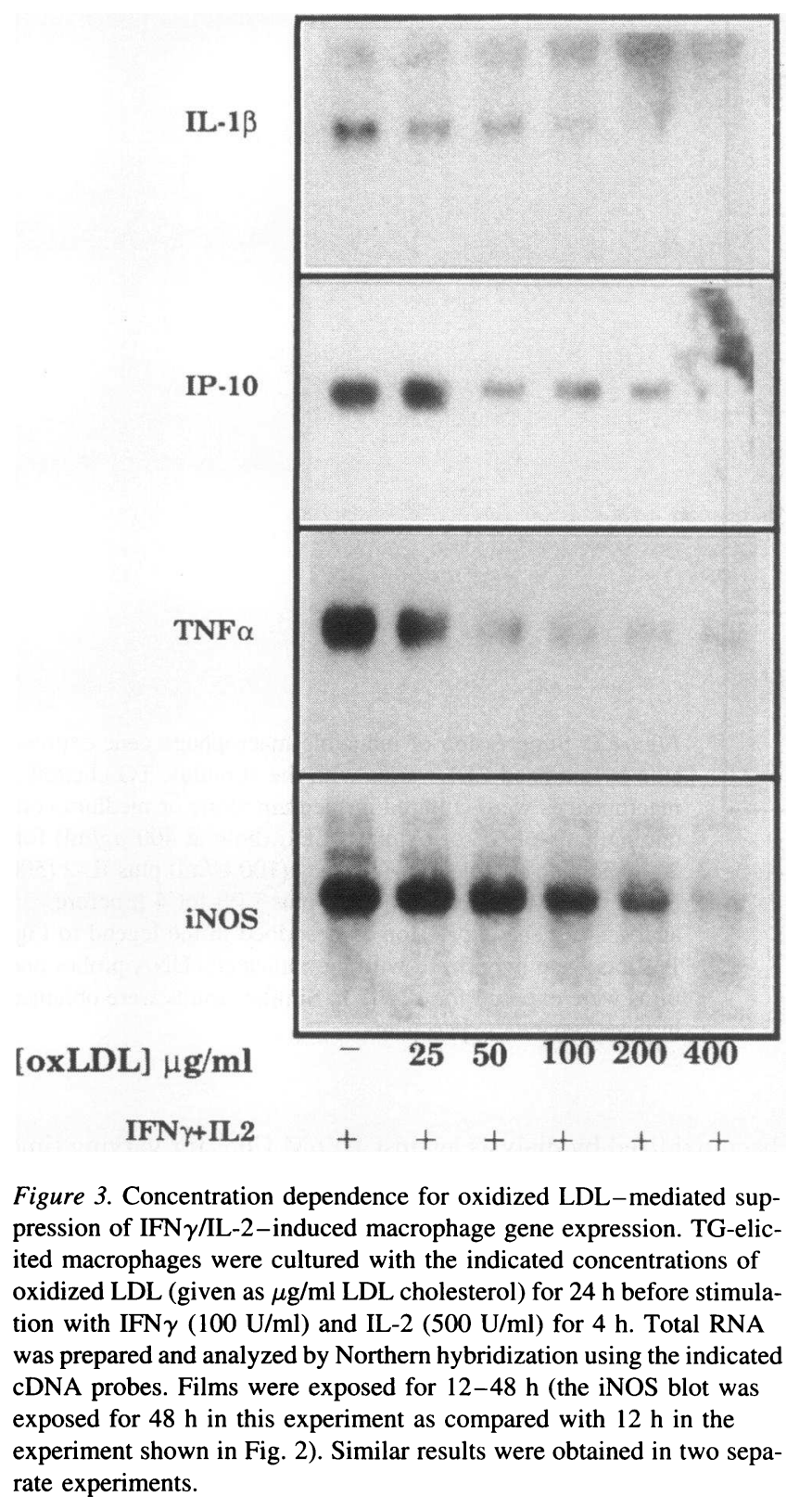

rate experiments.
Table I. Effect of Oxidized LDL on TNF $\alpha$ Secretion*

\begin{tabular}{lc}
\hline \multicolumn{1}{c}{ Treatment } & TNF $\alpha$ (\% inhibition) \\
\hline & $p g / m l$ \\
LPS & $2354 \pm 156$ \\
LPS + oxLDL & $1160 \pm 35(51)$ \\
IFN $\gamma+$ IL-2 & $2201 \pm 60$ \\
IFN $\gamma+$ IL-2 + oxLDL & $231 \pm 7(90)$ \\
\hline
\end{tabular}

$* 1 \times 10^{6}$ TG-elicited macrophages in 2-cm-diameter wells were cultured in the presence or absence of oxidized LDL ( $400 \mu \mathrm{g} / \mathrm{ml})$ for 24 $h$. The culture medium was changed and the cells were stimulated with LPS $(10 \mathrm{ng} / \mathrm{ml})$ or IFN $\gamma(100 \mathrm{U} / \mathrm{ml})$ and IL-2 $(500 \mathrm{U} / \mathrm{ml})$ for $24 \mathrm{~h}$. The culture supernatants were used for assay of TNF $\alpha$ by ELISA according to the manufacturer's instructions.

impact of oxidized LDL on inflammatory function appears to be variable depending at least in part on the cell type(s) being examined and the extent of LDL oxidation (6-14). Regulation of inflammation involves stringent control of gene expression within participating cell types such as macrophages. There are many different genes involved and many different agents capable of providing both positive and negative stimulation (4244). The results of the present study clearly demonstrate that inducible gene expression is not uniformly affected by oxidized LDL; whether expression is suppressed varies with the particular gene product under examination and with the stimulus used to elicit expression. These conclusions are based on the following observations. First, LPS-induced expression of IL- $1 \beta$, IP$10, \mathrm{TNF} \alpha, \mathrm{D} 3$, and D8 mRNAs was differentially suppressed by pretreatment of macrophages with oxidized LDL. Second, unmodified or native LDL from the same preparation as that used for oxidation had no effect on the expression of any inducible gene studied. Third, expression of TNF $\alpha$ and IP-10 is much more sensitive to suppression when induced by IFN $\gamma / \mathrm{IL}-2$ than when induced by LPS. Lastly, the cooperative stimulation by IFN $\gamma$ and LPS of iNOS mRNA expression was sensitive to oxidized LDL while the antagonistic effect of IFN $\gamma$ on LPSinduced TNFRII mRNA was not altered. While these differential effects of oxidized LDL in a complex system are exemplary and do not predict the behavior of other genes, the variability underscores the importance of defining the repertoire of in-

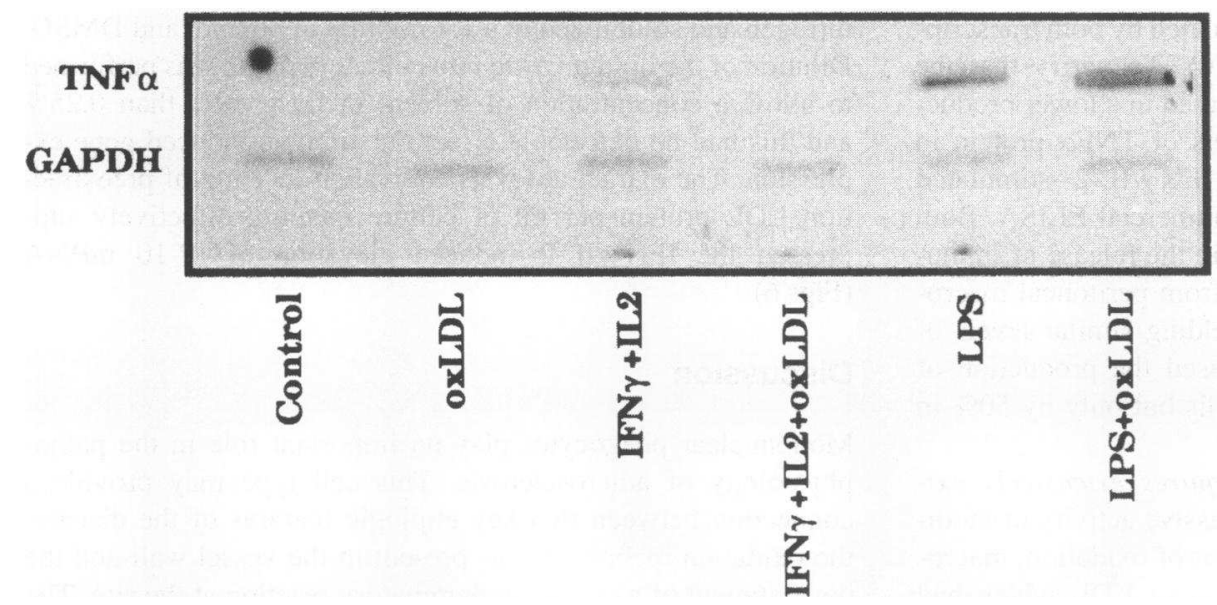

Figure 4. Oxidized LDL selectively suppresses transcription of TNF $\alpha$ mRNA induced by IFN $\gamma / \mathrm{IL}-2$. TG-elicited macrophages were untreated or treated with oxidized LDL ( $400 \mu \mathrm{g} / \mathrm{ml})$ for $24 \mathrm{~h}$ before stimulation with IFN $\gamma / \mathrm{IL}-2$ or LPS for $2 \mathrm{~h}$ as described in the legend to Fig. 2. Nuclei were harvested and used for nuclear runon analysis as described in Methods. Blots of cDNA encoding either TNF $\alpha$ or GAPDH were hybridized with radiolabeled primary transcripts and the film was exposed for $5 \mathrm{~d}$. Similar results were obtained in two separate experiments. 


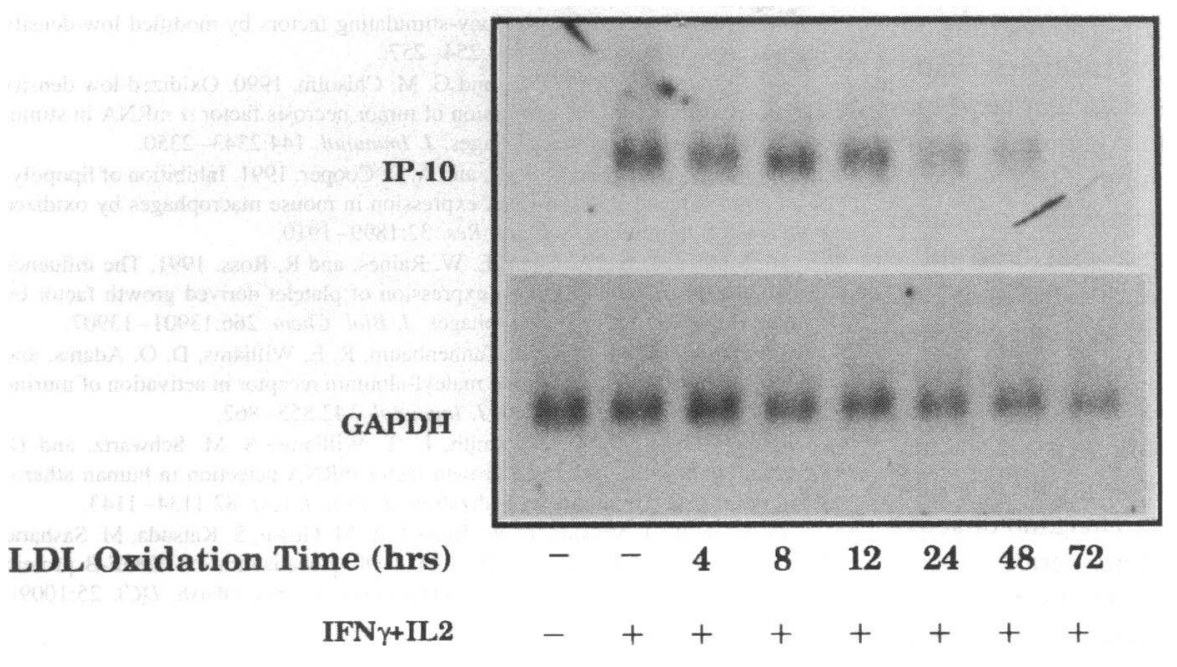

Figure 5. LDL requires extensive oxidation time for acquisition of suppressive activity. Native LDL was dialyzed against sterile pyrogen free PBS containing $10 \mu \mathrm{M} \mathrm{Cu}^{2+}$ for the indicated times before analysis of suppressive activity on IFN $\gamma / \mathrm{IL}-2$-induced IP10 mRNA expression. TG elicited macrophages were either untreated (control), treated with IFN $\gamma(100 \mathrm{U} / \mathrm{ml})$, and IL-2 $(500$ $\mathrm{U} / \mathrm{ml}$ ), or pretreated for $24 \mathrm{~h}$ with LDL oxidized as above for the indicated times before treatment with IFN $\gamma$ and IL-2 and analysis of IP-10 mRNA by Northern hybridization as described in the legend to Fig. 2. Similar results were obtained in two separate experiments. flammatory products generated at sites of atherogenesis and identifying the stimuli which may be operative at such sites.

The differential effects of oxidized LDL on macrophage gene expression have significant implications for understanding the mechanisms involved in controlling inflammatory gene expression. First, it is clear that multiple intracellular signaling events are involved in mediating the inflammatory response of this cell type to the diverse collection of extracellular stimuli (44-46). It is interesting that these signaling pathways exhibit differential sensitivity to oxidized LDL. The mechanisms of action of oxidized LDL are not the result of a broad toxicity directed at general metabolic machinery of the cell, but rather function in a more selective fashion. The signaling pathways mediating responses to IFN $\gamma$, IL-2, and LPS in macrophages are, however, only partially understood and specific targets of oxidized LDL have not been identified as yet. Nevertheless, the selectivity of the suppressive effects of oxidized LDL and its lipid components may represent an important issue to exploit in developing interventional therapies for atherogenesis and related chronic inflammatory diseases.

Our findings indicate that the transcription of certain genes is a primary mechanistic target of oxidized LDL. These findings do not rule out the contribution of posttranscriptional, translational, and posttranslational mechanisms. Indeed, oxidized LDL suppressed the production of TNF $\alpha$ protein by $50 \%$ under conditions where there was no detectable alteration in levels of TNF $\alpha$ mRNA (compare Table I with Figs. 1 or 2). This is consistent with the known importance of translational regulation of TNF $\alpha$ biosynthesis (40).

Several laboratories have examined the effects of modified LDL on the expression of various cytokine genes in cells capable of contributing to inflammatory reactions in vivo. These include not only mononuclear phagocytes but vascular endothelial cells as well. Both stimulatory and suppressive effects have been observed though the differences are likely related to the cell types and gene products under study and the nature and magnitude of the modification of the LDL particles (12-16). Indeed, modestly oxidized LDL has been found to promote the expression of several cytokine genes in vascular endothelial cells, and the stimulatory effects on gene expression have also been demonstrated in vivo $(12,13,47)$. Other reports suggest that the predominant effect of oxidized LDL on macrophages is the suppression of gene expression induced in response to conventional stimuli such as LPS (14-16). In the present study the majority of suppressive activity was generated only after extensive oxidation of the LDL particle and was not demonstrable either in unmodified LDL or in LDL subjected to only moderate oxidation. In addition, the suppressive activity is contained within the lipid fraction as it can be extracted with chloroform/methanol. Thus even though the oxidation of LDL also causes substantial changes in the structure of the protein moiety (i.e., apo B100) (41), these changes do not appear to contribute to the suppressive activity demonstrated on macrophages. The spectrum of oxidized lipid products which may be found within the extensively oxidized LDL used here is undoubtedly large. Several biologic activities of oxidized LDL have been attributed to lysophospholipids $(7,11)$. Furthermore, $7-\beta$-hydroperoxycholesterol and related compounds are at least partially responsible for the toxicity of oxidized LDL on proliferating cultured cells (48). Neither lysophosphatidylcholine nor 7- $\beta$-hydroperoxycholesterol is able to replicate the effects on gene expression reported here (Hamilton, T. A., and G. M. Chisolm, unpublished observations).

What is the pathophysiologic significance of suppressing

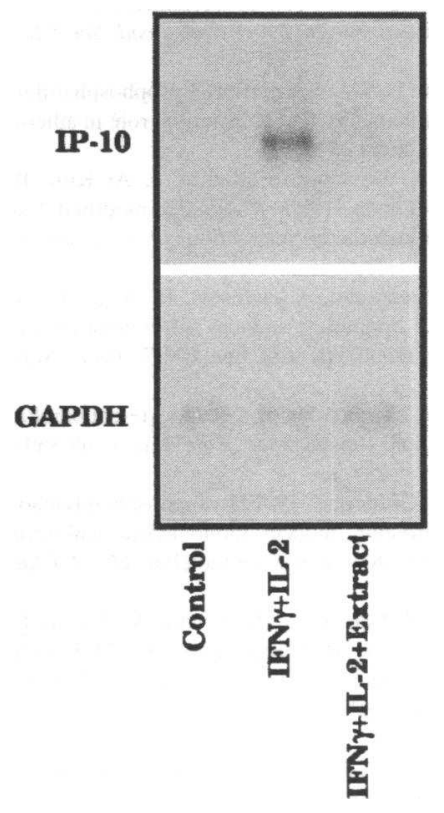

Figure 6. The suppressive activity of oxidized LDL is extractable with chloroform/methanol. TG-elicited macrophages were either untreated (Control) or stimulated with IFN $\gamma$ and IL-2 for $4 \mathrm{~h}$ after pretreatment of the cells with solvent (1:400 dilution of ethanol/DMSO, 1:1) alone or a chloroform/methanol extract of oxidized LDL redissolved in solvent. The final concentration of the oxidized LDL extract was based upon the equivalent of $1 \mathrm{mg}$ of the original LDL protein/ml culture medium. Total RNA was prepared and analyzed for IP-10 or GAPDH mRNAs by Northern hybridization as described in the legends to Figs. 1 and 2. Similar results were obtained in three separate experiments. 
macrophage inflammatory gene expression? Though this remains unknown, it is possible to consider a speculative scenario. During normal inflammation, macrophages and other cell types must generate soluble cytokine mediators to communicate with one another and allow coordinated orchestration of cell behavior leading to the normal resolution of inflammation and restoration of health. LDL, bound to extracellular matrix structures in the vessel wall, may be subject to increasing oxidative modification. Such modified LDL could be recognized and taken up by macrophages leading to the accumulation within foam cells of oxidized lipids. Those cells taking up the extensively oxidized LDL may be subject to appreciable dampening of the normal inflammatory response, thus allowing the development of a state of chronic, low-level inflammation to evolve. This kind of activity would be consistent with the extended time periods apparently required for the conversion of fatty streaks to mature atheromas. Suppression of cytokine expression at the site may be an important contributing feature of the pathophysiologic process.

\section{Acknowledgment}

This work was supported by U. S Public Health Service grant HL29589.

\section{References}

1. Gerrity, R. G. 1981. The role of the monocyte in atherogenesis. I. Transition of blood-borne monocytes into foam cells in fatty lesions. Am. J. Pathol. 103:181 189.

2. Watanabe, T., M. Hirata, Y. Yoshikawa, Y. Nagafuchi, H. Toyoshimna, and T. Watanabe. 1985. Role of macrophages in atherosclerosis. Sequential observations of cholesterol-induced rabbit aortic lesion by the immunoperoxidase technique using monoclonal anti-macrophage antibody. Lab. Invest. 53:80-90.

3. Ross, R. 1986. The pathogenesis of atherosclerosis - an update. N. Engl. J. Med. 314:488-500

4. Ross, R. 1993. The pathogenesis of atherosclerosis: a perspective for the 1990s. Nature (Lond.). 362:801-809.

5. Rosenfeld, M. E., J. C. Khoo, E. Miller, S. Parthasarathy, W. Palinski, and J. L. Witzum. 1991. Macrophage-derived foam cells freshly isolated from rabbit atherosclerotic lesions degrade modified lipoproteins, promote oxidation of lowdensity lipoproteins, and contain oxidation-specific lipid protein adducts. J. Clin. Invest. 87:90-99.

6. Quinn, M. T., S. Parthasarathy, L. G. Fong, and D. Steinberg. 1987. Oxidatively modified low density lipoproteins: a potential role in recruitment and retention of monocyte/macrophages during atherogenesis. Proc. Natl. Acad. Sci. USA. 84:1995-1999.

7. Quinn, M. T., S. Parthasarathy, and D. Steinberg. 1988. Lysophosphatidylcholine: a chemotactic factor for human monocytes and its potential role in atherogenesis. Proc. Natl. Acad. Sci. USA. 85:2805-2809.

8. Berliner, J. A., M. C. Territo, A. Sevanian, S. Ramin, J. Ai Kim, B. Bamshad, M. Esterson, and A. M. Fogelman. 1990. Minimally modified low density lipoprotein stimulates monocyte endothelial interactions. J. Clin. Invest. 85:1260-1266.

9. Frostegard, J., J. Nilsson, A. Haegerstrand, A. Hamsten, H. Wigzell, and M. Gidlund. 1990. Oxidized low density lipoprotein induces differentiation and adhesion of human monocytes and the monocytic cell line U937. Proc. Natl. Acad. Sci. USA. 87:904-908.

10. Chisolm, G. M. 1993. Oxidized lipoproteins and leukocyte-endothelial interactions: growing evidence for multiple mechanisms. Lab. Invest. 68:369371.

11. Kume, N., M. Cybulsky, and M. Gimbrone. 1992. Lysophosphatidylcholine, a component of atherogenic lipoproteins, induces mononuclear leukocyte adhesion molecules in cultured human and rabbit arterial endothelial cells. J. Clin. Invest. 90:1138-1144.

12. Cushing, S. D., J. A. Berliner, A. J. Valente, M. C. Territo, M. Navab, F. Parhami, R. Gerrity, C. J. Schwartz, and A. M. Fogelman. 1990. Minimally modified low density lipoprotein induces monocyte chemotactic protein 1 in human endothelial cells and smooth muscle cells. Proc. Natl. Acad. Sci. USA. 87:5134-5138.

13. Rajavashisth, T. B., A. Andalibi, M. C. Territo, J. A. Berliner, M. Navab, A. M. Fogelman, and A. J. Lusis. 1990. Induction of endothelial cell expression of granulocyte and macrophage colony-stimulating factors by modified low-density lipoproteins. Nature (Lond.). 344:254-257.

14. Hamilton, T. A., G. Ma, and G. M. Chisolm. 1990. Oxidized low density lipoprotein suppresses the expression of tumor necrosis factor $\alpha$ mRNA in stimulated murine peritoneal macrophages. J. Immunol. 144:2343-2350.

15. Fong, L. G., T. A. T. Fong, and A. D. Cooper. 1991. Inhibition of lipopolysaccharide induced IL- $1 \beta$ mRNA expression in mouse macrophages by oxidized low density lipoprotein. J. Lipid. Res. 32:1899-1910.

16. Malden, L. T., A. Chait, E. W. Raines, and R. Ross. 1991. The influence of oxidatively modified LDL on expression of platelet derived growth factor by human monocyte-derived macrophages. J. Biol. Chem. 266:13901-13907.

17. Haberland, M. E., C. S. Tannenbaum, R. E. Williams, D. O. Adams, and T. A. Hamilton. 1989. Role of the maleyl-albumin receptor in activation of murine peritoneal macrophages in vitro. J. Immunol. 142:855-862.

18. Wilcox, J. N., K. M. Smith, L. T. Williams, S. M. Schwartz, and D. Gordon. 1988. Platelet-derived growth factor mRNA detection in human atherosclerotic plaques by in situ hybridization. J. Clin. Invest. 82:1134-1143.

19. Ross, R., J. Masuda, E. W. Raines, A. M. Gown, S. Katsuda, M. Sashara L. T. Malden, H. Masuko, and H. Sato. 1990. Localization of PDGF-B protein in macrophages in all phases of atherogenesis. Science (Wash. DC). 25:10091012.

20. Barath, P., M. C. Fishbein, J. Cao, J. Berenson, R. H. Helfant, and J. S Forrester. 1990. Detection and localization of tumor necrosis factor in human atheroma. Am. J. Cardiol. 65:295-302.

21. Nelken, N. A., S. R. Coughlin, D. Gordon, and J. N. Wilcox. 1990. Monocyte chemoattractant protein-1 in human atheromatous plaques. J. Clin. Invest. 88:1121-1127.

22. Yla-Herttuala, S., B. A. Lipton, M. E. Rosenfeld, T. Sarkioja, T. Yoshimura, E. J. Leonard, J. L. Witztum, and D. Steinberg. 1991. Expression of monocyte chemoattractant protein 1 in macrophage-rich areas of human and rabbit atherosclerotic lesions. Proc. Natl. Acad. Sci. USA. 88:5252-5256.

23. Clinton, S. K., R. Underwood, L. Hayes, M. L. Sherman, D. W. Kufe, and P. Libby. 1992. Macrophage colony-stimulating factor gene expression in vascular cells and in experimental and human atherosclerosis. Am. J. Pathol. $2: 301-316$

24. Rosenfeld, M. E., S. Yla-Herttuala, B. A. Lipton, V. A. Ord, J. L. Witztum, and D. Steinberg. 1992. Macrophage colony-stimulating factor mRNA and protein in atherosclerotic lesions of rabbits and humans. Am. J. Pathol. 140:291-300.

25. Tannenbaum, C. S., T. J. Koerner, M. M. Jansen, and T. A. Hamilton. 1988 Characterization of lipopolysaccharide-induced macrophage gene expression. $J$. Immunol. 140:3640-3645.

26. Hamilton, T. A., N. Bredon, Y. Ohmori, and C. S. Tannenbaum. 1989 IFNgamma and IFNbeta independently stimulate the expression of lipopolysaccharide-inducible genes in murine peritoneal macrophages. J. Immunol 142:2325-2331.

27. Meltzer, M. S. 1978. Tumoricidal responses in vitro of peritoneal macrophages from conventionally housed and germ free nude mice. Cell. Immunol. 75:176-187.

28. Pennica, D., J. S. Hayflick, T. S. Bringman, M. A. Palladino, and D. V. Goeddel. 1985. Cloning and expression in Escherichia coli of the cDNA for tumor necrosis factor. Proc. Natl. Acad. Sci. USA. 82:6060-6064.

29. Ohmori, Y., G. Strassmann, and T. A. Hamilton. 1990. cAMP differentially regulates expression of mRNA encoding IL- $1 \alpha$ and IL- $1 \beta$ in murine peritoneal macrophages. J. Immunol. 145:3333-3339.

30. Ohmori, Y., and T. A. Hamilton. 1990. A macrophage LPS-inducible early gene encodes the murine homologue of IP-10. Biochem. Biophys. Res. Commun. 168:1261-1267.

31. Tannenbaum, C. S., J. A. Major, and T. A. Hamilton. 1993. IFN $\gamma$ and LPS differentially modulate expression of TNF receptor mRNAs in murine peritoneal macrophages. J. Immunol. 151:6833-6839.

32. Deng, W., B. Thiel, C. S. Tannenbaum, T. A. Hamilton, and D. Stuehr. 1993. Synergistic cooperation between $T$ cell lymphokines for induction of the nitric oxide synthase gene in murine peritoneal macrophages. J. Immunol. 151:322-329.

33. Tannenbaum, C. S., J. A. Major, Y. Ohmori, and T. A. Hamilton. 1993. A lipopolysaccharide-inducible macrophage gene (D3) is a new member of an interferon-inducible gene cluster and is selectively expressed in mononuclear phagocytes. J. Leukocyte Biol. 53:563-568.

34. Sambrook, J., E. F. Fritsch, and T. Maniatis. 1989. Molecular Cloning: A Laboratory Manual. 2nd ed. Cold Spring Harbor Laboratory, Cold Spring Harbor, NY.

35. Chirgwin, J. M., R. J. Pryzbyla, R. J. MacDonald, and W. J. Rutter. 1979. Isolation of biologically active RNA from sources enriched in ribonuclease. Biochemistry. 18:5295-5299.

36. Bligh, E. G., and W. J. Dyer. 1959. A rapid method of total lipid extraction and purification. Can. J. Biochem. Physiol. 37:911-916.

37. Narumi, S., J. H. Finke, and T. A. Hamilton. 1990. Interferon $\gamma$ and interleukin 2 synergize to induce selective monokine expression in murine peritoneal macrophages. J. Biol. Chem. 265:7036-7041.

38. Xie, Q., R. Whisnant, and C. F. Nathan. 1993. Promoter of the mouse 
gene encoding calcium independent nitric oxide synthase confers inducibility by interferon gamma and bacterial lipopolysaccharide. J. Exp. Med. 177:1779-1784.

39. Lorsbach, R. B., W. J. Murphy, C. J. Lowenstein, S. H. Snyder, and S. W. Russell. 1993. Expression of the nitric oxide synthase gene in mouse macrophage activated for tumor cell killing. Molecular basis for the synergy between interferon-gamma and lipopolysaccharide. J. Biol. Chem. 268:1908-1913.

40. Han, J., T. Brown, and B. Beutler. 1990. Endotoxin responsive sequences control cachectin/tumor necrosis factor biosynthesis at the translational level. $J$. Exp. Med. 171:465-475.

41. Fong, L. G., S. Parthasarathy, J. L. Witzum, and D. Steinberg. 1987. Non enzymatic oxidative cleavage of peptide bonds in apoprotein B100. J. Lipid. Res. 28:1466-1477.

42. Adams, D. O., and T. A. Hamilton. 1992. Macrophages as destructive cells in host defense. In Inflammation: Basic Principles and Clinical Correlates. Raven Press, New York. 637-662.

43. Nathan, C. F. 1987. Secretory products of macrophages. J. Clin. Invest. 79:319-326
44. Adams, D. O., and T. A. Hamilton. 1992. Molecular basis of macrophage activation: diversity and its origins. In The Natural Immune System, Volume II: The Macrophage. C. E. Lewis and J. O. D. McGee, editors. Oxford University Press, Oxford. 75-114.

45. Adams, D. O. 1992. LPS-initiated signal transduction pathways in macrophages. In Bacterial Endotoxic Lipopolysaccharides. D. C. Morrison and J. L. Ryan, editors. CRC Press, New York. 285-310.

46. Hamilton, T. A., Y. Ohmori, J. M. Tebo, S. Narumi, and C. S. Tannenbaum. 1993. Transmembrane and intracellular signaling events in LPS-stimulated macrophages. In Macrophage Pathogen Interactions. B. Zwilling and T. Eisenstein, editors. Marcel Dekker, Inc., New York. 83-97.

47. Liao, F., J. A. Berliner, M. Mehrabian, M. Navab, L. L. Demer, A. J. Lusis, and A. M. Fogelman. 1991. Minimally modified low density lipoprotein is biologically active in vivo in mice. J. Clin. Invest. 87:2253-2257.

48. Chisolm, G. M., G. Ma, K. C. Irwin, L. L. Martin, K. G. Gunderson, L. F. Linberg, D. W. Morel, and P. E. DiCorleto. 1994. $7 \beta$-hydroperoxycholest5 -en-3 $\beta$-ol, a component of human atherosclerotic lesions, is a primary cytotoxin of oxidized low density lipoprotein. Proc. Natl. Acad. Sci. USA. 91:11452-11456. 